Full-text Available Online at www.ajol.info and www.bioline.org.br/ja

\title{
Cultivation, Isolation and Characterization of Bacteriocin from Fresh Cow Milk and Meat Samples obtained from Lapai Market in Niger State Nigeria.
}

\author{
${ }^{* 1,2}$ BALOGU, TV; ${ }^{1} \mathrm{JOHN}, \mathrm{J} ;{ }^{1}$ ABDULSALAM A \\ ${ }^{I}$ Department of Microbiology, Ibrahim BadamasiBabangidaUniversity, Lapai \\ ${ }^{2}$ Department of Food Science and Technology, Ibrahim BadamasiBabangida University, Lapai \\ * Corresponding author tovin2009@yahoo.com
}

\begin{abstract}
This study focus on cultivation, isolation and characterization of Bacteriocin from fresh cow milk (FCM) and fresh cow meat (FMS) samples obtained from Lapai Market in Niger State, Nigeria. Potential bacteriocinogenic bacteria were screened with agar diffusion method on culture plates seeded with Staphylococcus and E.coli. Bacteriocinogenic isolates from FCM were Enterococcus faeciumFCM5 and Bacillus megaterium FCM6, while isolates from FMS include Bacillusbadius FMS1 and Micrococcus varians FMS2. Bacteriocins produced were assayed with pre-enriched MRS broth culture incubated at $30^{\circ} \mathrm{C}$ with adjusted $\mathrm{pH}(7.1)$ for $48 \mathrm{hrs}$ and stored $\left(4^{0} \mathrm{C}\right)$. The primed cultures were centrifuged $(20,000 \mathrm{rpm})$ for $30 \mathrm{mins}$, supernatant were filtered $(0.2 \mu \mathrm{m}$ membrane filters), precipitated with ammonium sulphate and steam sterilized $\left(121{ }^{0} \mathrm{C}\right.$ at $15 \mathrm{psi}$ ) for $15 \mathrm{mins}$. Bacteriocin-like products (BLPs) were crystallized and tagged enterocin FCM5, bacillocin FCM6, bacillocin FMS1 and micrococin FMS2 according to bacteriocinogenic isolates' typing. After $48 \mathrm{hrs}$, Bacteriocinogenic load ranged between 5.1 - 6.13Log10 cfu/mL. Biopreservative indexes (BI) of BLPs $(0.25-0.75 \mathrm{mg} / \mathrm{mL})$ were effective against predominant food spoilers (Saccharomyces, Pseudomonas, Klebsiellaand Micrococcusspp isolated from range of beverages, starchy and meaty meals). Quantified BLPs $(20$ - $1880 \mathrm{IU} / \mathrm{mL})$ strengths had no direct correlation with the antibacterial spectral (6 - 19mm) expressed as zone of inhibition. Thus, efficacy of BLPs observed in this study, were not a function of BLP quantity but quality. Conclusively,Enterocin FCM5, Bacilliocins (FCM6 and FMS1) and Micrococin FMS2 are thermal and pressure stable BLPs that are effective against predominant food spoilers. CJASEM
\end{abstract}

\section{https://dx.doi.org/10.4314/jasem.v21i3.2}

Keywords: Bacteriocin, cultivation, milk, meat, Lapai, bacteriociongenic

Bacteriocins are proteinous metabolites of bacteria that have inhibitory activities against some related or non-related bacteria (Zhou et al., 2014). However, non-bacterial species such as fungi (Adebayo and Aderiye, 2010) are susceptible to bacteriocin. Popular among them are nisin, pediocin, colicin, aureocin, agrocin, alveicin, lactococin, divercin, subtilin, leucoccin, lacticin, cuvaaticin, triflioxin, halocin, thuricin etc.

Prominent lactic acid bacteria (LAB) that synthesizes bacteriocin-like products include pediococci, lactococci, lactobacilli, and enterococci. Bacteriocinlike products in combination with hydrogen peroxides, lactic acid and other organic acids are metabolites of LABs that naturally preserve foods from spoilage microbes. Most dominant LABs in fermented and non-fermented foods are good producers of bacteriocins. LABs that synthesize bacteriocins have been isolated from different food types and beverages such as beers, milk, fermented cucumber, cheese (Rekhef et al., 1995 Moham etal., 2012, Gonzales et al., 1994; Van Reenen et al., 1998) and fermented vegetables (Zhou et al.2014). The nutritive nature of meat products makes them a good medium that support broad spectrum of spoilage and benefious bacteria. LABs with bacteriocin-like metabolites have been isolated from meat products (Bromberg et al. 2004).

Global food safety agencies envisaged a world of healthy foods with natural food preservatives, which are generally regarded as safe (GRAS). Bacteriocins (Nisin) status as GRAS (Mohammed et al., 2016), have increased detailed studies on the potency and application of other bacteriocin as natural alternative substance for food preservations. Successful antimicrobial potencies of bacteriocins have been recorded (Mohammed et al., 2016; Gao et al. 2010). Most bacteriocins are progressively studied either as crude extract form, semi purified or purified form via culture sediments, precipitation (ammonium sulfate,

* Corresponding author tovin2009@yahoo.com 
methanol extraction) and chromatographic activity. Considering the health risk associated chemical preservatives, there is a growing advocacy for natural or organic food preservatives. Thus, this study aimed to cultivate, isolate and assess bacteriocin from fresh cow milk and meat samples obtained from Lapai Market in Niger State, Nigeria.

\section{MATERIALS AND METHOD}

Sample Collection:A total of $1000 \mathrm{~mL}$ and $1000 \mathrm{~g}$ of Fresh cow milk (FCM) and fresh meat samples (FMS) respectively were purchased from five different vendors at random locations in Lapai Market Niger state, Nigeria. Approximately from each vendor, $200 \mathrm{~mL}$ FCM and 200g of FMS were purchased and stored in sterile bottle and plastic bags respectively placed in ice bags $<4^{0} \mathrm{C}$ while on transit to the laboratory (IBB university Lapai). Each of the five samples (FCM and FMS) were bulked together and labelled as FCM and FMS. Leftover foods from IBB University, cafeterias were aseptically collected in sterile plastic bags, and transferred to laboratory for isolation of test/indicators organisms.

Microbial Isolation: Standard methods of culture media preparation were done according to methods of Cowan and steel (2004). From the bulked sample, $100 \mathrm{~mL}$ of FCM was diluted in $900 \mathrm{~mL}$ of distilled water and vigorously agitated for 1 minute. With sterile pipette, $1 \mathrm{~mL}$ of the solution was diluted serially with $0.1 \%$ peptone water upto the $3^{\text {rd }}$ fold and $1 \mathrm{~mL}$ of each sample were pour plated on lactic acid Bacteria medium (LABM), nutrient agar (oxoid) and De Man Rogosa sharpe (MRS) broth (Oxoid) incubated at $30^{\circ} \mathrm{C}$ for 24 hours. Similar protocols were replicated using $100 \mathrm{~g}$ of chopped $\left(\sim 2 \mathrm{~cm}^{3}\right)$ FMS steeped in distilled water overnight. Colonies were enumerated and expressed as Log $10 \mathrm{CFU} / \mathrm{mL}$. Pure colonies were obtained by subculturing isolates on fresh media and stored in slant agars prior to characterization using relevant biochemical test (Cowan and Steel, 2004).

Test/Indicator Organism Protocol: Staphylococcus aureus and E. coli were selected as indicator organisms to screen prospective bacteriocin producing isolates. Prominent strains from food samples were selected as the test organisms. Among the selected species, include Saccharomyces cerevisiae from beverages, Klebsiella sp (meat sample), Micrococcus varians (meat) and Pseudomonas sp (variety of carbohydrate solid foods).
Bacteriocin Assay: Screening and cultivation of Bacteriocin: Prospective bacteriocin synthesizing pure isolates of FCM and FMS were initially screened using agar well diffusion methods. Aliquots (50uL) of $48 \mathrm{hr}$ old pure cultures of FCM and FMS isolates were discharged into wells (7-mm diameter) of fresh nutrient agar culture plates seeded with either Staphylococcus aureus or E. coli as indicator organisms. Isolates with zone of inhibitions were designated as positive or otherwise negative. Only positive designated isolates were cultivated in $250 \mathrm{~mL}$ of pre-enriched MRS broth culture for 48 hours at $30^{\circ} \mathrm{C}$ with adjusted $\mathrm{pH}$ (7.1)and stored at $4{ }^{\circ} \mathrm{C}$ prior crude extract purification and quantification assays.

Crude Extraction, semi purification and quantification of Bacteriocin: Protocols for crude extract of bacteriocin were sequential by centrifuging primed culture $(48 \mathrm{hr}$ old $)$ at $20,000 \mathrm{rpm}\left(\leq 4{ }^{\circ} \mathrm{C}\right)$ for 30 mins. Supernatant of solution were adjusted to $\mathrm{pH}$ of 7.1, before filter sterilization using whiteman ${ }^{\circledR}$ membrane nylon filter $(0.2 \mu \mathrm{m})$ and $5 \mathrm{mg} / \mathrm{ml}$ catalase (C-100 bovine liver, Sigma) was added to eliminated peroxides and lactic acids effect (Kacem et al. 2005). The solution was tagged as bacteriocin crude extract (BCE) and used for bacteriocin antibacterial assays. BCEs were further precipitated with ammonium sulphate, steam sterilized $\left(121^{\circ} \mathrm{C}\right.$ at $\left.15 \mathrm{psi}\right)$ for 15 minutes and tagged as bacteriocin-like product (BLP). Quantification of BLPs were determined at spectrophotometric wavelength of $450 \mathrm{~nm}$ and expressed as IU $/ \mathrm{mL}$ equivalent of $\mathrm{Nisin}$ (Sigma, USA) standard solution.

Nisin Standardization Protocol: Nisin Standard was prepared according the methods of Papagianni et al. (2006) by adding $0.1 \mathrm{~g}$ of nisin to solution $(10 \mathrm{ml}$ $0.02 \mathrm{~N} \mathrm{HCl}$ and $0.75 \% \mathrm{NaCl}$ ) and steam sterilized at $121^{\circ} \mathrm{C}$ for 15 minutes at 15 psi and tagged standard nisin solution $\left(10^{5} \mathrm{UI} / \mathrm{ml}\right)$. From this standard solution, $0.2,0.4,0.6,0.8$ and 1.0 concentrations with index factor of $10^{3} \mathrm{IU} / \mathrm{mL}$ were prepared and used to plot standard nisin concentrationabsorbance(@450nm) chart with $R^{2}=0.959$.

Antibacterial assay: The antibacterial activity of the BCEs were determined using agar well diffusion method described by Mohammed et al., (2016) with slight modifications. From each BCEs, $10 \mathrm{~mL}$ was collected and labelled as $1.0 \mathrm{Au} / \mathrm{mL}$, and three sequential dilutions $(0.75 \mathrm{AU} / \mathrm{mL}, 0.5 \mathrm{AU} / \mathrm{mL}, 0.25$ $\mathrm{AU} / \mathrm{mL}$ ) were made from it. From each concentration, $500 \mu \mathrm{L}$ of each were drawn and discharged into 5-mm diameter wells in bioassay agar plates (with 5 wells per plate: 4 sample and 1 control) seeded with specific spectrum of test organisms. 
Distilled water was used as control on each plate. All plates were incubated at $37^{\circ} \mathrm{C}$ for $24 \mathrm{~h}$ and zone of inhibitions diameters were measured. Minimum inhibitory concentration (MIC) was determined using the least concentration of BCEs that induced Zone of inhibition and expressed as arbitrary units (AU) per $\mathrm{ml}(\mathrm{AU} / \mathrm{mL})$. Where $1 \mathrm{AU} / \mathrm{mL}=$ dilution factor of standardized solution of BLPs.

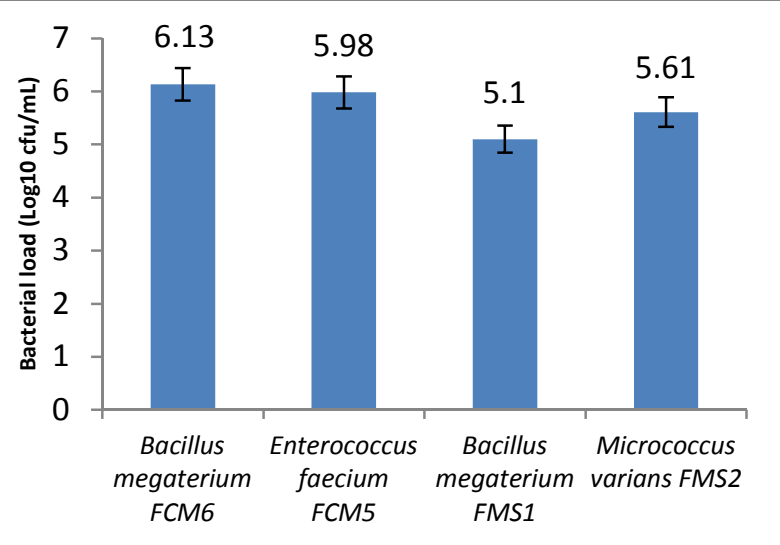

Fig. 1: Bacterial load of BLPs of Isolates from FCM and FMS

KEY : FCM = Fresh Cow Milk, FMS = Fresh Meat Sample, BLPs = Bacteriocin-like-products

\section{RESULTS AND DISCUSSION}

Bacteriocinogenic load cultivated for $48 \mathrm{hrs}$ at $30{ }^{0} \mathrm{C}$ with adjusted $\mathrm{pH}(7.1)$ were relatively stable at the range of $5.1 \mathrm{Log} \mathrm{cfu} / \mathrm{mL}-6.13 \log \mathrm{cfu} / \mathrm{mL}$ (Fig. 1). Irrespective of the source of Bacteriocinogenic isolates, there were no significantly different $(\mathrm{P}<0.05)$ among bacterial loads.Perhaps, similarity of the culture conditions was responsible for the stable bacterial kinetics. The ranges of bacterial loads were within the findings of Malheiros et al., (2015), which documented a range of $5.62-9.26 \log \mathrm{cfu} / \mathrm{mL}$. However, it seems that bacterial load have neither direct correlation with antibacterial spectral nor BLPs quantities within 48 hrs cultivation period.

Calibration curve for BLPs quantification was obtained using plot of absorbance value against concentration (UI/mL) of Nisin standard solution. The curve was resolved as linear model $(\mathrm{Y}=0.182 \mathrm{X})$ with coefficient $\left(R^{2}\right)$ of 0.959 (Fig. 2). The Chart was validated based on more than $95 \%$ confidence $\left(\mathrm{R}^{2}=\right.$ 0.959). Malheiros et al., (2015) used fitted models and coefficients ( $R^{2}$ values) for bacteriocin assays in their attempt to optimize the growth of bacteriocin production by Lactobacillus subsp. sakei $2 a$.

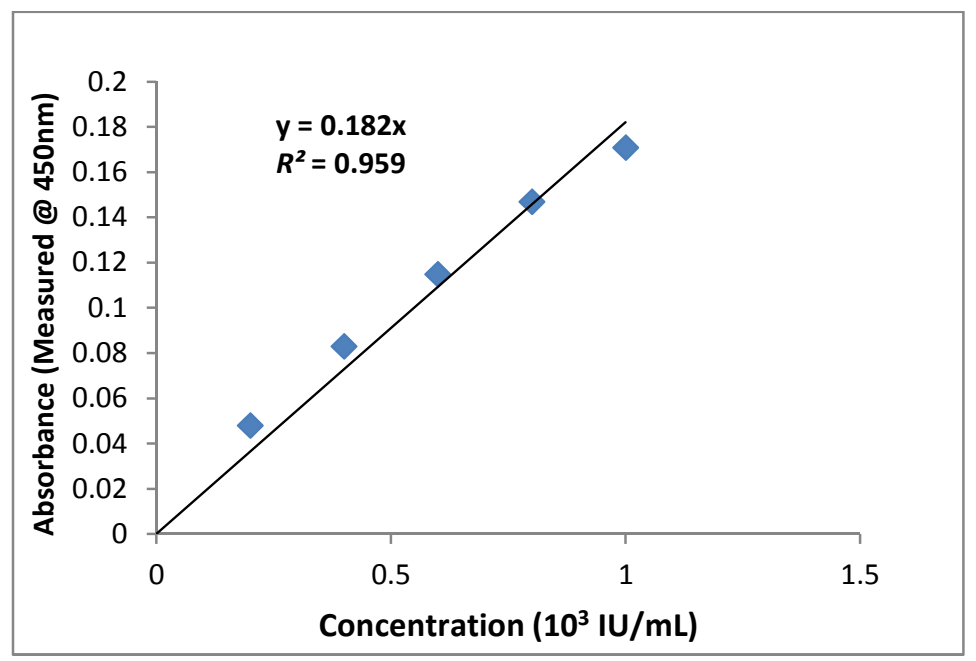

Fig. 2: Calibration curve of Nisin Standard solution for Quantifying BLPs concentration 
Similarly, Venigalla et al., (2017) validated the precision of quadratic models for bacteriocin assay based on the $\mathrm{R}^{2}$ values (0.911), which was significantly lower than the $\mathrm{R}^{2}(0.959)$ observed in This study. Perhaps, the purity level of the standardized Nisin (sigma USA) used in this study, accounted for the disparity compared to the crude bacteriocin of Venigalla et al., (2017).

Minimum inhibitory concentrations (MIC) were assessed and expressed as biopreservative index (BI) of bacteriocins (FCM and FMS). BLPs of FCM6 and
FMS1 with BI of $0.25 \mathrm{mg} / \mathrm{mL}$ each, were adjudged as better biopreservatives than FCM5 $(0.75 \mathrm{mg} / \mathrm{mL})$ and FMS1 $(0.50 \mathrm{mg} / \mathrm{mL})$. Test organisms to assay the BI of FCM5, FCM6, FMS1 and FMS2 were genera of Sacchromyces, Pseudomonas, Klebsiella and Micrococcus respectively (Table 1). Based on BI factor, bacteriocins of bacillocins (FCM6 and FMS1) would be efficient to preserve foods against bacterial spoilers of non-beverage than micrococin FMS 2, and enterococins FCM5 would be best to preserve beverages.

Table 1: Biopreservation Index of FCM and FMS Bacteriocins

\begin{tabular}{llll}
\hline BLPs & $\begin{array}{l}\text { MIC/BI } \\
(\mathrm{mg} / \mathrm{mL})\end{array}$ & $\begin{array}{l}\text { Test organism } \\
\text { (predominate isolate } \\
\text { from source) }\end{array}$ & $\begin{array}{l}\text { Source of indictor } \\
\text { organism }\end{array}$ \\
\hline Enterocin FCM5 & 0.75 & $\begin{array}{l}\text { Sacchromycesspp } \\
\text { Bacilliocin FCM6 }\end{array}$ & Beverages \\
Bacilliocin FMS1 & 0.25 & Pseudomonas spp & Starchy food \\
Micrococin FMS2 & 0.25 & Klebsiella sp. & Meaty foods \\
\hline
\end{tabular}

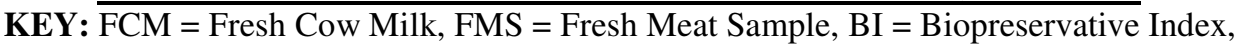
$\mathrm{BLP}=$ Bacteriocin-Like Products, MIC $=$ Minimum Inhibitory Concentrate.

Enterocin FCM5 from Enterococcus faecium, Bacillocin FCM6from Bacillusmegaterium, BacillocinFMS1 from Bacillus badius, Micrococin FMS2 from Micrococcus macquariensis

Assessing the quantity of BLPs after $48 \mathrm{hrs}$ at $30^{\circ} \mathrm{C}$ cultivation, showed that Micrococin FMS2 (1.88 $\mathrm{IU} / \mathrm{mL}$ ) was significantly high compared to decreasing order of Enterocin FCM5 (0.23 IU/mL),
BacillocinFCM6 (0.13 IU/mL), and Bacillocin FMS1 with $0.02 \mathrm{IU} / \mathrm{mL}$ (Fig. 3 ). The cultivation conditions $\left(\mathrm{pH} 7.1\right.$ and $30{ }^{\circ} \mathrm{C}$ ) seem to be optimal for Micrococin FMS2 synthesis.

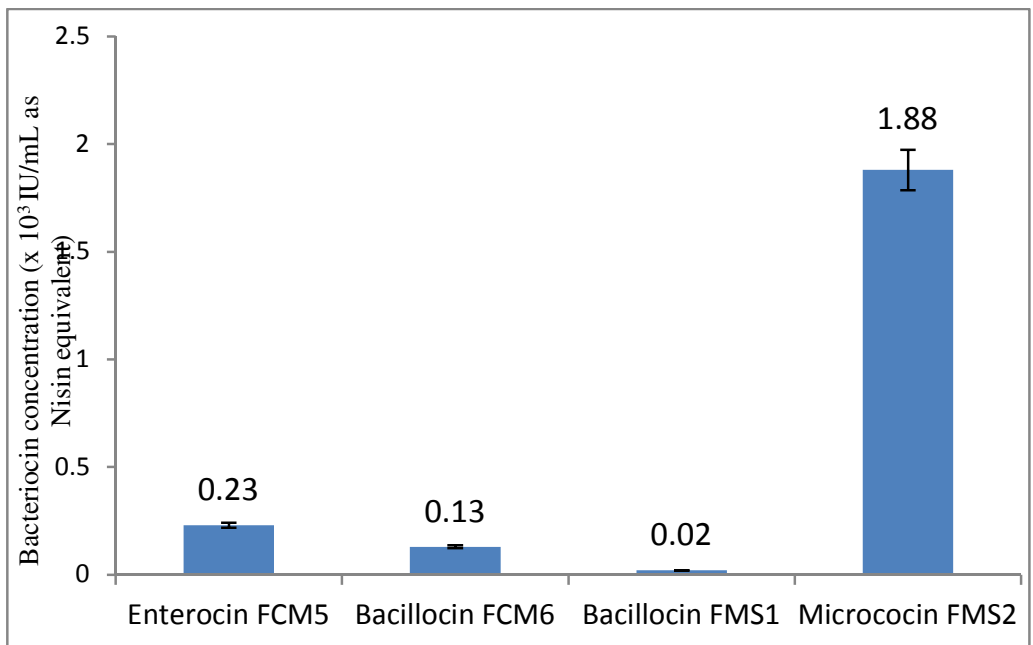

Fig. 3: Bacteriocin Activity/ Quantification of BLPs after $48 \mathrm{hrs}$ at $30^{\circ} \mathrm{C}$.

KEY: FCM = Fresh Cow Milk, FMS = Fresh Meat Sample, BLP = Bacteriocin-Like Products Enterocin FCM5 from Enterococcus faecium, Bacillocin FCM6 from Bacillusmegaterium, BacillocinFMS1 from Bacillus badius, Micrococin FMS2 from Micrococcus macquariensis

However, Papagianni et al., (2006), correlated the bacteriocin concentration and antibacterial assay (zone of inhibition). Their models seem to be species sensitive, as only one among three species of Lactobacillus plot was correlatively strong. Delgado et al. (2005) also demonstrated that quotients of linear parallel models of zone of inhibition and indicator organisms' sensitivity are capable of quantifying bacteriocin activity. Both references above utilized relativity principles to quantity 
bacteriocins, which are similar to the scope of this study that used absorbance relativity values expressed as equivalent of Nisin.

Bacillocins (FCM6 and FMS1) have the highest zone of inhibitions of $18 \mathrm{~mm}$ and $19 \mathrm{~mm}$ respectively when $1 \mathrm{ml}\left(\sim 10^{2} \mathrm{UI} / \mathrm{mL}\right.$ equivalent of Nisin) was tested against predominant bacterial food spoilers
(Pseudomonas and Klebsiella Spp). In declining trend, micrococin FMS2 (11mm) was effective against related species (Micrococcussp) and the least was enterocin FCM5 with $6 \mathrm{~mm}$ zone of inhibition against Saccharomyces spp (Fig. 4).Yang et al., (2012) observed that BLPs of lactobacillus species inhibited related species.

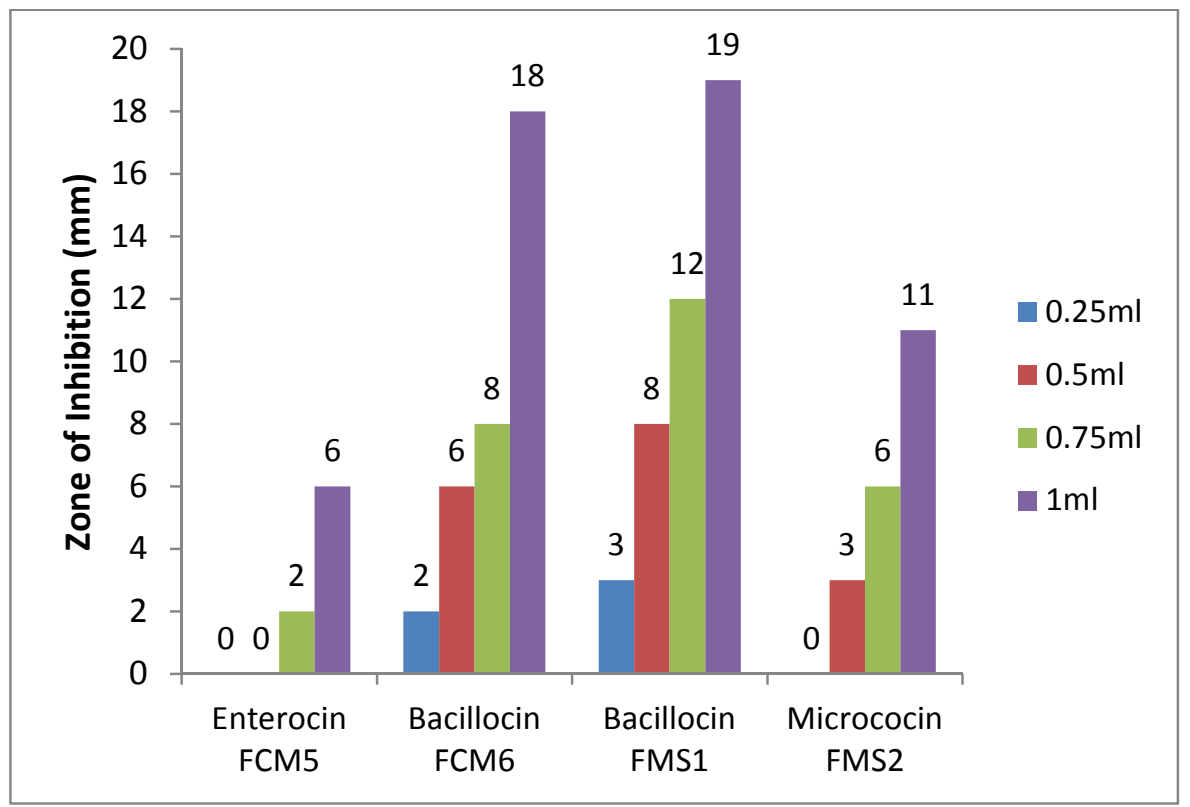

Fig 4: Antimicrobial Profiles of Bacteriocins Isolated from FCM and FMS

Key : $\quad$ FCM = Fresh Cow Milk, FMS = Fresh Meat Sample

Enterocin FCM5 from Enterococcus faecium, Bacillocin FCM6from Bacillusmegaterium, BacillocinFMS1 from Bacillus badius, Micrococin FMS2 from Micrococcus macquariensis

Similarly in this study, micrococin FMS2 inhibited Micrococcus sp. Previous studies of Mohammed et al. (2016); Yang et al., (2012) Papagianni et al. (2006), Sobrino-Lopez and Martı́n-Belloso (2008) and as well this study, observed inhibition of nonrelated species by BLPs. Obvious stability and antimicrobial activities of BLPs after treatments $\left(121^{\circ} \mathrm{C}\right.$ at $\left.15 \mathrm{psi}\right)$, confers heat and pressure stable status to BLPs of FCMs and FMSs. Some of the gram negative pressure-resistant bacteria such Pseudomonas and E. coli (Black et al., 2005), were effectively inhibited by BLPs of this study. Invariably, they could be possibly used in hurdle technology for preservation of pressure treated foods. Conclusively, BLPs of Enterocin FCM5, Bacilliocins (FCM6 and FMS1) and Micrococin FMS2 are thermal and pressure stable BLPs that are effective against predominant food spoilers.

\section{REFERENCES}

Adebayo, CO; Aderiye, BI (2010). Antifungal Activity of Bacteriocins of Lactic Acid Bacteria from Some Nigerian Fermented Foods. Res.J. Microbiol.5:1070-1082.

DOI: $10.3923 / \mathrm{jm} .2010 .1070 .1082$

Black, EP; Kelly, AL; Fitzgerald, GF (2005). The combined effect of high pressure and nisin on inactivation of microorganisms in milk. Innovative Food Sci. Emerging Technol, 6: 286292.

Bromberg, R; Moreno, I; Zaganini, CL; Delboni, RR; de Oliveira, J (2004). Isolation of Bacteriocin-Producing Lactic Acid Bacteria from Meat and Meat Products and its Spectrum of Inhibitory Activity. Braz. J. Microbiol. 35:137144.

Cowan, ST; Steel, KJ (2004). Manual for the Identification of Medical Bacteria (3rd ed.). Cambridge University Press. London. 331pp. 
Delgado, A; Brito, D; Fevereiro, P; Tenreiro, R; Peres, C (2005). Bioactivity quantification of crude bacteriocin solutions. J. Microbiol. Methods. 62, (1): 121-124.

Gao, Y; Jia, S; Gao, Q (2010). A novel bacteriocin with abroad inhibitory spectrum produced by Lactobacillus sake $\mathrm{C} 2$, isolated from traditional Chinese fermented cabbage. Food Ctrl. 21: 7681.

Gonzales, B; Arca, P; Mayo, B; Suarez, J (1994). Detection, purification and partial characterization of plantaricin C, a bacteriocinproduced by a Lactobacillus plantarum strain of dairy origin. Appl. Environ. Microbiol., 6: 2158-2163.

Kacem, M; Zadi-Karam, H; Karam, N (2005). Detection and activity of plantaricin OL15 a bacteriocin produced by Lactobacillus plantarum OL15 isolated from Algerian fermented olives. Grasasy Aceites.56 (3) :192- 197.

Malheiros, PS; Sant'Anna, V; Todorov, SD; Franco, BDGM (2015). Optimization of growth and bacteriocin production by Lactobacillus sakei subsp. sakei2a. Braz. J. Microbiol 46 (1): 825834. DOI: http://dx.doi.org/10.1590/S1517838246320140279.

Mohammed, SSD; Damisa, D; Balogu, TV; Bala, E (2016). Efficacy of Sakacin on Selected Food Pathogenic Microorganisms Isolated from Fermented Milk Products. J. Appl S. Environ Manag. 20(1): 97 - 101.
Papagianni, M; Avramidis, N; Filioussis, G; Dasiou, D; Ambrosiadis, I (2006). Determination of bacteriocin activity with bioassays carried out on solid and liquid substrates: assessing the factor "indicator microorganism." Microbial Cell Factories, 5, 30. http://doi.org/10.1186/14752859-5-30.

Sobrino-Lopez, A; Martı́n-Belloso, O (2008). Use of nisin and other bacteriocins for preservation of dairy products. Int'l Dairy J. 18: 329-343. doi:10.1016/j.idairyj.2007.11.009.

Van Reenen, CA; Dicks, LMT; Chikindas, ML (1998). Isolation, purification and partial characterization of plantaricin 423 , a bacteriocin produced by Lactobacillus plantarum. J. Appl. Microbiol., 84: 1131-1137.

Venigalla, S; Sindhuja, YN; Srujuna, K; Swathi, S; Naidu, Y; Rao, GH (2017). Optimized Production of Bacteriocin from Cheaper Carbon and Nitrogen Sources Using Response Surface Methodology. Res. J. Microbiol. 12: 42-49. DOI: $10.3923 / \mathrm{jm} .2017 .42 .49$

Yang, E; Fan, L; Jiang, Y; Doucette, C; Fillmore, S (2012). Antimicrobial activity of bacteriocin producing lactic acid bacteria isolated from cheeses and yogurts', AMB Express, 2 (48): 112. DOI: $10.1186 / 2191-0855-2-48$

Zhou, F; Zhao, H; Bai F; Piotr, D; Liu, Y; Zhang, B (2014): Purification and characterisation of the bacteriocin produced by Lactobacillus plantarum, isolated from Chinese pickle. Czech J. Food Sci., 32: 430-436. Czech J. Food Sci. 32(5): 430-436 